\title{
Kebijakan Pengembangan Budidaya Tanaman Bambu untuk Pengelolaan Berkelanjutan DAS Aesesa Flores
}

\section{Bamboo cultivation development policy for the sustainability management of Watershed Aesesa Flores}

Nicolaus Noywuli ${ }^{\mathrm{a}}$, Asep Sapei ${ }^{\mathrm{b}}$, Nora H. Pandjaitan ${ }^{\mathrm{c}}$, Eriyatno ${ }^{\mathrm{d}}$

aProgram Studi Ilmu Pengelolaan Sumberdaya Alam dan Lingkungan, Institut Pertanian Bogor; Pemkab Ngada - NTT.

bepartemen Teknik Sipil dan Lingkungan, Institut Pertanian Bogor

'Pusat Studi Pembangunan Pertanian dan Pedesaan, Institut Pertanian Bogor

\section{Article Info:}

Received: 03 - 12 - 2018

Accepted: $05-08$ - 2019

\section{Keywords:}

Bamboo, bioenergy, key factor, watershed, Aesesa Flores.

Corresponding Author:

Nicolaus Noywuli

Program Studi Ilmu Pengelolaan

Sumberdaya Alam dan

Lingkungan, Institut Pertanian

Bogor;

Tel. $+62-82236192567$

Email:

nicolausnoywuli@gmail.com

\begin{abstract}
The existence of Aesesa Flores (AF) watershed is very important for people in Ngada and Nagekeo Regency of Flores island. The AF watershed provides water, land use, economic and other environmental services. However, the excessive exploitation is a major threat for the existence of the $A F$ watershed. The degradation of the AF watershed function such as reduction in river debit, increase of critical land, land use change as well as the problem of poverty. The upstream area is intended as a conservation area where Watu Ata nature preservation park is located, the bamboo forest and Bajawa as the capital city of Ngada Regency. The downstream area is not only as capital city of Nageko Regency but also as paddy field area. One of the activity to improve the watershed function is through a comprehensive and sustainable management policy design based on characteristics and carrying capacity of the AF watershed. This research was conducted in April-May 2018 and the the purpose of the study is to analyzed key factors and establishing an alternative for sustainable management policy development of AF watershed using a prospective method. This study using mainly primary data obtained from the seven local experts through the filling of the questionnaire. The result shows that there are 22 attribute factors and it identified as 10 key factors. The main two key factors are bamboo cultivation, processing technology of bamboo, enlargement of bamboo cultivation area and practicing the soil and water conservation technique. The 10 key factors then become input for designing the management policy of AF watershed. Bamboo become the dominant and key factor because bamboo could be developed into biomass energy plant and it serves social, economic and ecological values for the local people of Ngada and Nagekeo Regency. Bamboo cultivation has a good prospect financially for the local people.
\end{abstract}

How to cite (CSE Style $8^{\text {th }}$ Edition):

Noywuli N, Sapei A, Pandjaitan NH, Eriyatno. Kebijakan pengembangan budidaya tanaman bambu untuk pengelolaan berkelanjutan DAS Aesesa Flores. JPSL 9(4): 946-959. http://dx.doi.org/10.29244/jps1.9.4. 946-959.

\section{PENDAHULUAN}

Pengelolaan Daerah Aliran Sungai Aesesa Flores (DAS AF) seluas 129005 ha yang berada tengah Pulau Flores Provinsi Nusa Tenggara Timur (NTT) ini, perlu mendapatkan perhatian dan menjadi prioritas berbagai pihak, dikarenakan beberapa hal sebagai berikut: 1) Debit air salah satu mata air (mukufoka) di hulu DAS Aesesa Flores yang digunakan oleh PDAM Bajawa terus menurun, dimana pada tahun 2003 sebesar 26.7 lt/dt 
menjadi 22.3 lt/dt pada tahun 2007; 2) Hutan bambu sebagai water catchment di Kabupaten Ngada terus menurun sampai saat ini tersisa seluas $\pm 13 \%$ dari luas DAS Aesesa Flores (Koli 2010); 3) Mayoritas masyarakat Kabupaten Ngada dan Nagekeo Provinsi NTT (75\%) menggantungkan hidupnya pada SDA dan lingkungan di DAS Aesesa Flores. Di sisi lain, belum ada kelembagaan lokal dan kebijakan khusus (otonomi) yang menangani pengelolaan DAS Aesesa secara terpadu dan berkelanjutan (Pujiono dan Setyowati 2015). Lebih lanjut Noywuli et al. (2019), mengemukan bahwa DAS AF saat ini dalam kondisi buruk daya dukungnya, sehingga perlu segera dipulihkan. Buruknya kondisi daya dukung DAS AF lebih disebabkan oleh kriteria lahan (lahan kritis seluas 98000 ha) dan kriteria sosial ekonomi (kemiskinan). Kondisi daya dukung DAS AF yang terburuk terjadi di bagian hulu, disusul bagian hilir dan tengah. Pemulihan kondisi daya dukung DAS AF dapat dilakukan dengan kegiatan penataan ruang wilayah DAS, pemberdayaan masyarakat, serta konservasi tanah dan air.

Pengelolaan DAS sebagaimana diatur dalam Peraturan Pemerintah No. 37 Tahun 2012, merupakan upaya manusia dalam mengatur hubungan timbal balik antara sumber daya alam dengan manusia di dalam DAS dan segala aktivitasnya, agar terwujud kelestarian dan keserasian ekosistem serta meningkatnya kemanfaatan sumberdaya alam bagi manusia secara berkelanjutan. Sehingga untuk tercapainya tujuan pengelolaan DAS AF yang berkelanjutan, maka diperlukan pengembangan kebijakan dalam pengelolaannya.

Pengembangan kebijakan pengelolaan DAS AF merupakan skenario kebijakan yang didasarkan pada faktor kunci atau dominan yang mempunyai pengaruh tinggi dan memiliki ketergantungan terhadap sistem yang dikaji, dalam hal ini sistem DAS AF. Faktor yang perlu dikelola adalah faktor yang memiliki pengaruh tinggi terhadap tingkat keberlanjutan, sehingga mampu mendorong kinerja sistem pengelolaan untuk mencapai tujuan sistem. Faktor lainnya yang dikelola adalah faktor dengan ketergantungan yang rendah sehingga mampu mencapai kinerja tanpa tergantung terhadap faktor lainnya, sedangkan faktor dengan ketergantungan yang tinggi maka perlu dikelola secara lebih hati-hati karena dapat mempengaruhi ketidakstabilan di dalam sistem.

Salah satu faktor yang memiliki pengaruh tinggi terhadap tingkat keberlanjutan pengelolaan DAS AF adalah tanaman bambu (Bambuseae). Tanaman bambu dapat tumbuh dan berada pada semua bagian dengan luasan yang berbeda. Masyarakat di DAS AF sudah membudaya dengan bambu, dan menjadikan bambu sebagai tanaman wajib yang berfungsi SEE (sosial, ekonomi dan ekologi). Secara sosial, bambu biasa digunakan dalam ritual adat dan menjadi persyaratan dalam pertunanganan terutama di bagian hulu. Secara ekonomi, bambu menjadi bahan bangunan rumah dan bangunan/kandang ternak, juga menjadi sumber pendapatan dengan menjual bambu. Secara ekologi, bambu ditanam pada daerah mata air, dan menahan erosi yang ditanaman pada daerah dengan kemiringan tinggi, juga sepanjang sempadan sungai. Widnyana (2011) membenarkan bahwa bambu dapat bernilai ekonomi tinggi bagi masyarakat dan sekaligus berguna untuk rehabilitasi daerah hutan dan lahan kritis karena menyerap $\mathrm{CO}_{2}$ dan air hujan. Dengan demikian bambu dapat menjadi salah satu faktor atau komoditi yang perlu dipertimbangkan dalam pengelelolaan DAS AF yang berkelanjutan. Pentingnya bambu dalam kehidupan masyarakat Kabupaten Ngada juga dapat dilihat dari sebutan Kabupaten Ngada sebagai kabupaten sejuta bambu (Ramadhan 2016). Saat ini, Kabupaten Ngada juga telah ditetapkan sebagai salah satu kabupaten pusat pengembangan bambu Indonesia oleh kementerian LHK melalui program pemanfaatan bambu berbasis masyarakat (Ekawati 2018).

Disamping itu, pemintaan bambu akhir-akhir ini semakin meningkat yang berakibat terjadinya exploitasi bambu rakyat secara besar-besaran terutama terhadap jenis bambu tertentu, sehingga tidak seimbang dengan usaha perbanyakan dan penanaman kembali, disamping itu akan berpotensi terjadinya lahan kritis bila tidak segera diadakan penanganan. Oleh karena itu perlu dikembangkan penanaman dalam bentuk perkebunan / pembudidayaan bambu yang dapat dilakukan pada lahan tidak produktif. Dengan demikian bambu dapat meningkatkan produktivitas lahan. Berdasarkan hal tersebut, maka penelitian ini bertujuan menentukan faktor kunci yang dijadikan sebagai agenda pengelolaan DAS AF dan pengembangan bambu sebagai alternatif kebijakan pengelolaan berkelanjutan dari masing-masing bagian DAS Aesesa Flores. 


\section{METODE}

\section{Lokasi dan Waktu Penelitian}

Penelitian ini dilaksanakan di wilayah yang termasuk bagian hulu (upstream), tengah (middle stream) dan hilir (down stream) DAS Aesesa Flores yang terletak diantara Kabupaten Ngada dan Nagekeo Provinsi NTT (Gambar 1). Waktu pelaksanaan penelitian adalah mulai bulan April sampai Mei 2018.

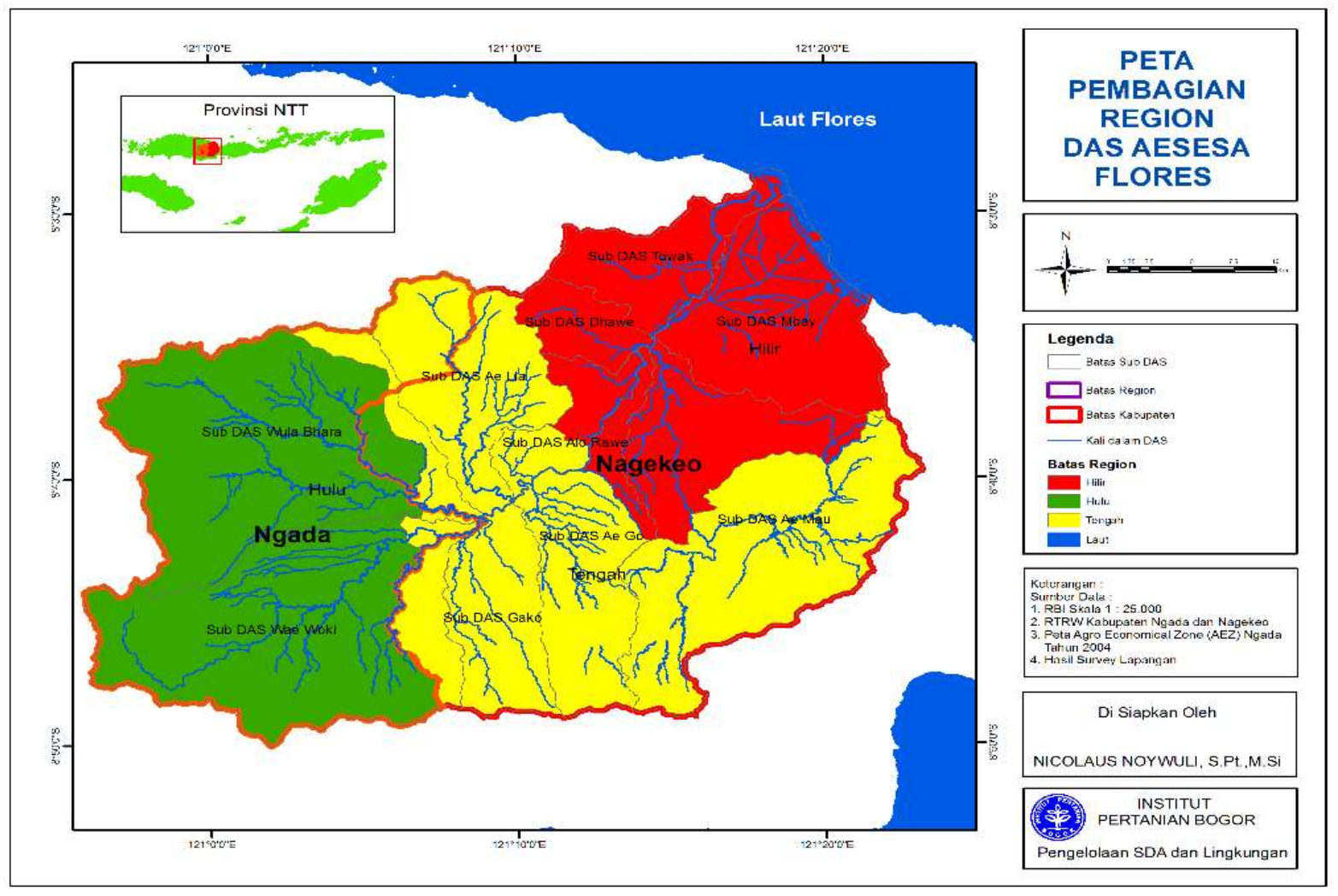

Gambar 1 Peta Lokasi dan Bagian DAS AF.

\section{Metode Pengumpulan Data}

Jenis dan sumber data yang dikumpulkan terdiri dari data primer dan data sekunder. Data primer diperoleh dari hasil kuesioner dan wawancara pakar serta observasi lapangan. Data primer diperoleh dari responden yang dipilih dengan sengaja, yaitu seseorang yang dianggap pakar/ahli. Jumlah responden terdiri atas 7 (tujuh) ahli/pakar mengacu pada Hora (2004) yang menyebutkan bahwa jumlah pakar yang memadai adalah sebanyak 3-7 orang. Para pakar yang dipilih mewakili unsur akademisi, peneliti dan pejabat pemerintah baik tingkat propinsi NTT maupun dari Kabupaten Ngada dan Nagekeo yang memiliki pemahaman tentang DAS AF. Pemenuhan prinsip triangulasi data dilakukan dengan cara melakukan wawancara dengan informan yang dipilih dengan sengaja, yang merupakan aparat instansi daerah terkait. Tujuannya adalah untuk memperkaya data primer atau pembahasannya.

Data sekunder diperoleh dari studi pustaka dalam rangka memperoleh landasan teoritis dan data penunjang yang berkaitan dengan materi penelitian. Data sekunder berupa laporan tahunan atau teknis dari instansi terkait serta laporan hasil penelitian, jurnal ilmiah dan publikasi lainnya yang ada di lembaga penelitian atau internet. 


\section{Metode Analisis Data}

Salah satu bentuk analisis kebijakan adalah analisis prospektif (Dunn 2000). Analisis prospektif merupakan salah satu analisis yang banyak digunakan untuk merumuskan alternatif kebijakan berupa skenario strategis yang berkaitan dengan pengelolaan sumberdaya alam, industri atau pun masalah lainnya untuk mencapai kondisi yang efektif dan efisien pada masa mendatang (Hardjomidjojo 2007).

Menurut Bourgeois and Jesus (2004), analisis prospektif merupakan suatu metode yang digunakan untuk menganalisis permasalahan dalam sistem ahli yang dapat menggabungkan pembuat keputusan dalam rangka menyusun kembali beberapa perencanaan dengan pendekatan yang berbeda. Analisis prospektif merupakan suatu alat yang secara efektif dapat memetakan kepentingan stakeholders terhadap suatu wilayah. Dari analisis ini didapatkan suatu konsensus dari interaksi antara stakeholders yang akan digunakan untuk perencanaan (Bourgeois and Jesus, 2004; Godet, 2010). Analisis prospektif dapat digunakan sebagai alat untuk mengeksplorasi dan mengantisipasi perubahan melalui skenario. Dapat juga sebagai alat normatif yang merupakan pendekatan berorientasi tindakan yang dimulai dari visi terpilih mengenai masa depan dan menentukan jalur untuk mencapainya. Dengan demikian, analisis prospektif tidak berfokus pada optimasi solusi, tetapi pada penyediaan berbagai macam pilihan dan tujuan bagi para pembuat keputusan dan turut merancang serangkaian alternatif ketimbang memilih alternatif terbaik (Bourgeois, 2007).

(Hardjomidjojo 2007), mengurai tahapan dalam melakukan analisis prospektif sebagai berikut:

1. Menentukan faktor kunci untuk masa depan dari sistem yang dikaji. Pada tahap ini dilakukan identifikasi seluruh faktor kunci dengan menggunakan kriteria faktor variabel. Kemudian, dilakukan analisis, menggunakan matriks pengaruh dan ketergantungan sistem, untuk melihat pengaruh faktor terhadap kinerja sistem dan ketergantungan antar faktor sebagai elemen-elemen dalam sistem. Analisis Prospektif terhadap sistem pengelolaan berkelanjutan DAS AF dikelompokkan kedalam 4 (empat) kuadran yaitu kuadran I = INPUT atau faktor penentu (driving varables), kuadran II = STAKE atau faktor penghubung (leverage variables), kuadran III = OUTPUT atau faktor terikat (output variables), dan kuadran IV = UNUSED atau faktor bebas (marginal variables). Faktor yang masuk kedalam kuadran I dan kuadran II merupakan faktor kunci dengan karakteristik memiliki pengaruh yang kuat dan dengan ketergantungan terhadap sistem yang rendah (kuadran I) dan kuat (kuadran II). Dalam pengelolaan sumberdaya DAS maka diharapkan banyak faktor yang berada di kuadran I sehingga pengelolaan faktor lebh mudah. Sebaliknya, tidak diharapkan banyak faktor yang berada di kuadran II karena faktor ini memiliki pengaruh dan ketergantungan yang besar terhadap sistem, sehingga dibutuhkan pengelolaan yang lebih hati-hati. Bourgeois (2007) menyatakan bahwa terdapat 2 tipe sebaran variabel-variabel dalam matriks pengaruh dan ketergantungan, yaitu: 1). Tipe sebaran yang cenderung mengumpul pada diagonal kuadran II ke kuadran IV. Tipe ini menunjukkan bahwa sistem yang dibangun tidak stabil karena sebagian besar variabel-variabel yang dihasilkan termasuk variabel marginal atau leverage variabel. Hal ini menyulitkan dalam membangun skenario strategis untuk masa mendatang; dan 2) Tipe sebaran variabel yang mengumpul di kuadran I ke kuadran 11l. Tipe ini mengindikasikan sistem yang dibangun stabil, karena memperlihatkan hubungan yang kuat dimana variabel penggerak mengatur variabel output dengan kuat. Selain itu, dengan tipe ini maka skenario strategis bisa dibangun lebih mudah dan efisien.

2. Menentukan tujuan strategis dan kepentingan pelaku utama.

3. Mendefinisikan dan mendeskripsikan evolusi kemungkinan masa depan, pada tahapan ini dilakukan identifikasi bagaimana elemen kunci dapat berubah dengan menentukan keadaan (state) pada setiap faktor, memeriksa perubahan mana yang dapat terjadi bersamaan dan menggambarkan skenario dengan memasangkan perubahan yang akan terjadi dengan cara mendiskusikan skenario dan implikasinya terhadap sistem. 


\section{HASIL DAN PEMBAHASAN}

\section{Identifikasi Faktor Kunci (Dominan)}

Faktor dominan yang berpengaruh dalam sistem pengelolaan bagian DAS AF diperoleh dari identifikasi hasil analisis daya dukung DAS AF, kelembagaan pengelolaan DAS AF, dan terutama dilakukan terhadap faktor pengungkit (leverage factor) dari setiap dimensi keberlanjutan (Noywuli et al. 2017a, 2017b, Suwarno 2011 dan Surya 2015). Hasil identifikasi faktor dominan tersebut kemudian dipadukan lagi dengan kondisi karaktristik DAS AF dan hasil studi pustaka termasuk berbagai peraturan perundangan yang terkait, maka faktor pengungkit (dominan) pengelolaan berkelanjutan bagian DAS AF diperoleh sebanyak 22 faktor yang disajikan pada Tabel 1. Berdasarkan faktor dominan atau pengungkit yang diperoleh tersebut, kemudian dilakukan penilaian tingkat pengaruh dan tingkat ketergantungan antar faktor menggunakan analisis prospektif.

Tabel 1 Faktor Pengungkit Pengelolaan Berkelanjutan Pengelolaan DAS AF.

\begin{tabular}{cll}
\hline No. & Faktor/Atribut Kunci Pengelolaan Berkelanjutan DAS_AF & Simbol \\
\hline 1 & Kapasitas daya dukung DAS (dimensi ekologi) & KDD-DAS \\
2 & Perubahan lahan bervegetasi menjadi lahan terbangun (dimensi ekologi) & PLB-LT \\
3 & Tingkat penutupan lahan bervegetasi (dimensi ekologi) & TPLB \\
4 & Kekeringan dan kebakaran hutan (dimensi ekologi) & KKH \\
5 & Perluasan areal tanaman bambu dan tanaman KTA lainnya (dimensi ekologi) & PATB-KTA \\
6 & Penataan kawasan (permukiman dan pesisir) (dimensi ekologi) & PK-PP \\
7 & Tingkat pendapatan masyarakat (dimensi ekonomi) & TPM \\
8 & Iklim investasi (dimensi ekonomi) & IKIN \\
9 & Luas kepemilikan lahan pertanian (dimensi ekonomi) & LKLP \\
10 & Akses sumberdaya, jaminan pasar input dan output budidaya pertanian & ASJP \\
& (dimensi ekonomi) & \\
11 & Layanan PDAM (dimensi ekonomi) & L-PDAM \\
12 & Tingkat kepadatan penduduk (dimensi sosial) & TKP \\
13 & Motivasi, kepedulian dan partisipasi masyarakat dalam pengelolaan dan & MKPM-SDAL \\
& pengendalian SDAL (dimensi sosial) & \\
14 & Tingkat kesejahteraan masyarakat (dimensi sosial) & TKM \\
15 & Teknologi pengelolaan Sumber Daya Alam dan Lingkungan (dimensi teknologi) & T-PSDAL \\
16 & Teknologi Konservasi Tanah dan Air (dimensi teknologi) & TKTA \\
17 & Teknologi budidaya dan pengelolaan bambu (dimensi teknologi) & TBPB \\
18 & Kapasitas organisasi dan koordinasi lembaga/ instansi stakeholders terkait & KOKL \\
& (dimensi kelembagaan) & \\
19 & Rezim kepemilikan SDA pada DAS (dimensi kelembagaan) & RK-SDA \\
20 & Ketersediaan peraturan perundagan terkait dan penegakan hukum & KPPH \\
21 & Kelembagaan pengelolaan DAS berkelanjutan (dimensi kelembagaan) & \\
\hline & Kapasitas lembaga/instansi BPDAS (dimensi kelembagaan) & KP-DAS \\
& & KL-BPDAS \\
\hline
\end{tabular}

\section{Faktor Dominan Pengelolaan Bagian Hulu DAS Aesesa Flores}

Faktor dominan dalam pengelolaan bagian hulu DAS-AF menjadi sangat penting mengingat dampak yang dapat ditimbulkan, bila pengelolaannya tidak berkelanjutan. Bagian Hulu DAS adalah suatu wilayah daratan bagian dari DAS yang dicirikan dengan topografi bergelombang, berbukit dan atau bergunung, kerapatan drainase relatif tinggi, merupakan sumber air yang masuk ke sungai utama dan sumber erosi yang sebagian 
terangkut menjadi sedimen di daerah hilir. Berdasarkan fungsinya, bagian hulu memiliki fungsi konservasi yang dikelola untuk mempertahankan kondisi lingkungan DAS agar tidak terdegradasi, yang antara lain dapat diindikasikan dari kondisi tutupan vegetasi lahan DAS, kualitas air, kemampuan menyimpan air (debit), dan curah hujan (Asdak 2010). Kondisi bagian hulu DAS AF saat ini tidak sebagaimana fungsi hulu tersebut, karena juga terdapat kota Bajawa sebagai ibukota Kabupaten, sehingga tidak hanya fungsi konservasi tetapi juga fungsi budidaya seiring pertumbuhan penduduk.

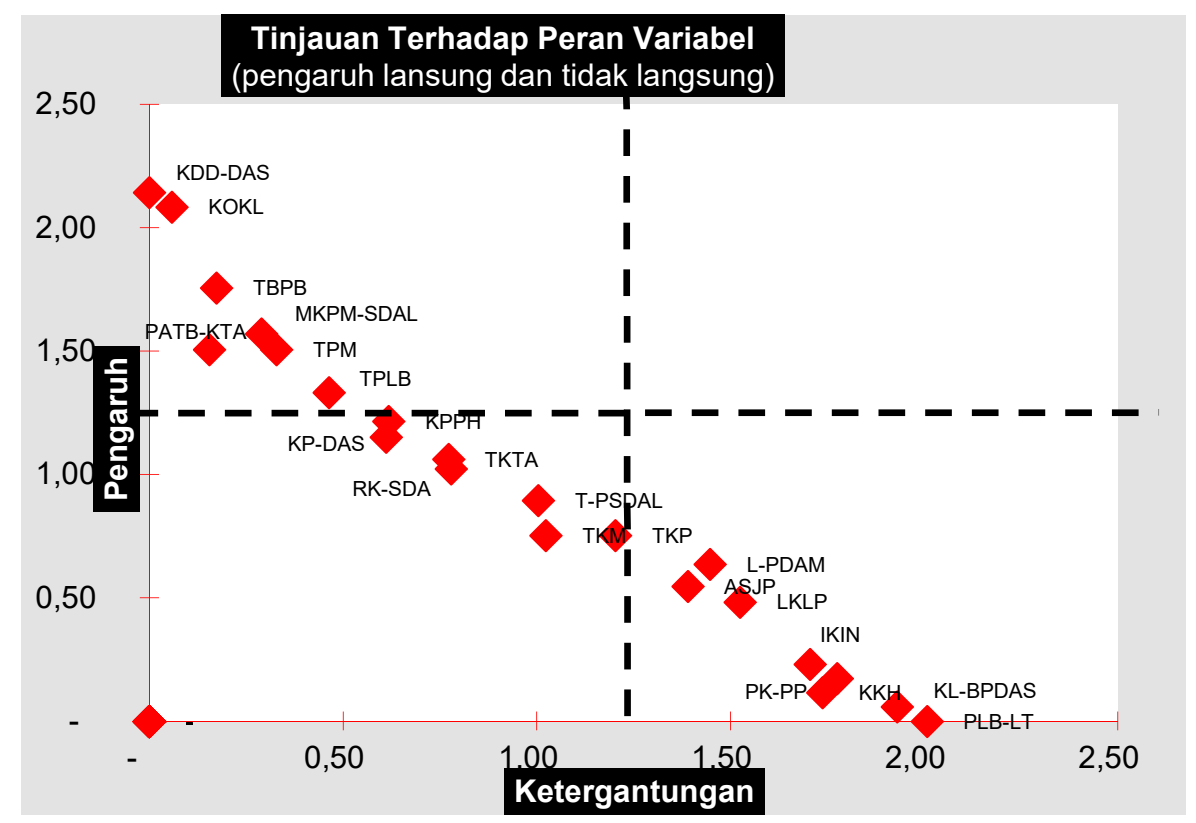

Gambar 2 Hasil analisis tingkat pengaruh Faktor pada pengelolaan bagian hulu DAS Aesesa Flores.

Berdasarkan hasil analisis (Gambar 2), diketahui tipe pola sebaran faktor-faktor pengungkit dalam kuadran adalah membentuk diagonal antara kuadran I dan III. Tipe sebaran variabel tersebut menunjukkan indikasi sistem yang dibangun valid. Hasil analisis prospektif terhadap pengelolaan bagian hulu DAS AF, diperoleh 7 (tujuh) faktor/variabel yang berada pada kuadran I (kuadran input) yang merupakan kuadran variabel penentu (driving variabels), terdiri atas; 1) KDD-DAS (kapasitas daya dukung DAS), 2) KOKL (kapasitas organisasi dan koordinasi lembaga/instansi stakeholders terkait, 3) MKPM-SDAL (motivasi dan kepedulian serta partisipasi masyarakat terhadap pengelolaan dan pengendalian SDAL), 4) Tingkat pendapatan masyarakat, 5) PATB-KTA (perluasan areal tanaman bambu dan tanaman KTA lainnya), 6) TBPB (teknologi budidaya dan pengelolaan bambu), dan 7) TPLB (Tingkat penutupan lahan bervegetasi). Ketujuh faktor/variabel tersebut merupakan variabel penentu dalam pengelolaan DAS AF bagian hulu secara berkelanjutan.

Hasil analisis faktor dominan bagian hulu DAS AF ini sejalan dengan hasil penelitian Suwarno (2011) bahwa faktor yang dominan (kunci) di dalam sistem DAS Ciliwung Hulu adalah faktor yang memiliki pengaruh yang tinggi terhadap kinerja sistem sebanyak 5 (lima) faktor yaitu : (1) kegiatan penyuluhan pertanian, perikanan dan kehutanan, (2) pemanfaatan jasa wisata, (3) perubahan lahan menjadi lahan terbangun, (4) alternatif pendapatan petani dari kegiatan non-pertanian, dan (5) kapasitas koordinasi instansi pemerintah. Kelima faktor tersebut mempunyai pengaruh yang besar terhadap kinerja sistem DAS Ciliwung Hulu sehingga perlu dikelola dengan lebih baik. 


\section{Faktor Dominan Pengelolaan Bagian Tengah DAS Aesesa Flores}

Bagian tengah DAS AF didasarkan pada fungsi pemanfaatan air sungai yang dikelola untuk dapat memberikan manfaat bagi kepentingan sosial dan ekonomi, yang antara lain dapat diindikasikan dari kuantitas air, kualitas air, kemampuan menyalurkan air, dan ketinggian muka air tanah, serta terkait pada prasarana pengairan seperti pengelolaan sungai, waduk, dan danau. Ciri atau karakteristik DAS bagian tengah adalah 1) Wilayah pada umumnya merupakan kawasan dataran yang relatif landai, 2) Proses erosi berlangsung secara vertikal dan lateral secara seimbang sehingga membentuk lembah yang biasanya menyerupai huruf "U", 3) Disekitar badan sungai banyak dijumpai batu-batu guling yang permukaannya relatif bulat dengan ukuran yang relatif kecil dibandingkan batuan di daerah hulu, dan 4) Keberadaan jeram dan air terjun jarang dijumpai atau bahkan tidak ada (Asdak 2010). Gambar 2 adalah hasil analisis prospektif terhadap faktor-faktor pengungkit dalam pengelolaan bagian tengah DAS AF secara berkelanjutan.

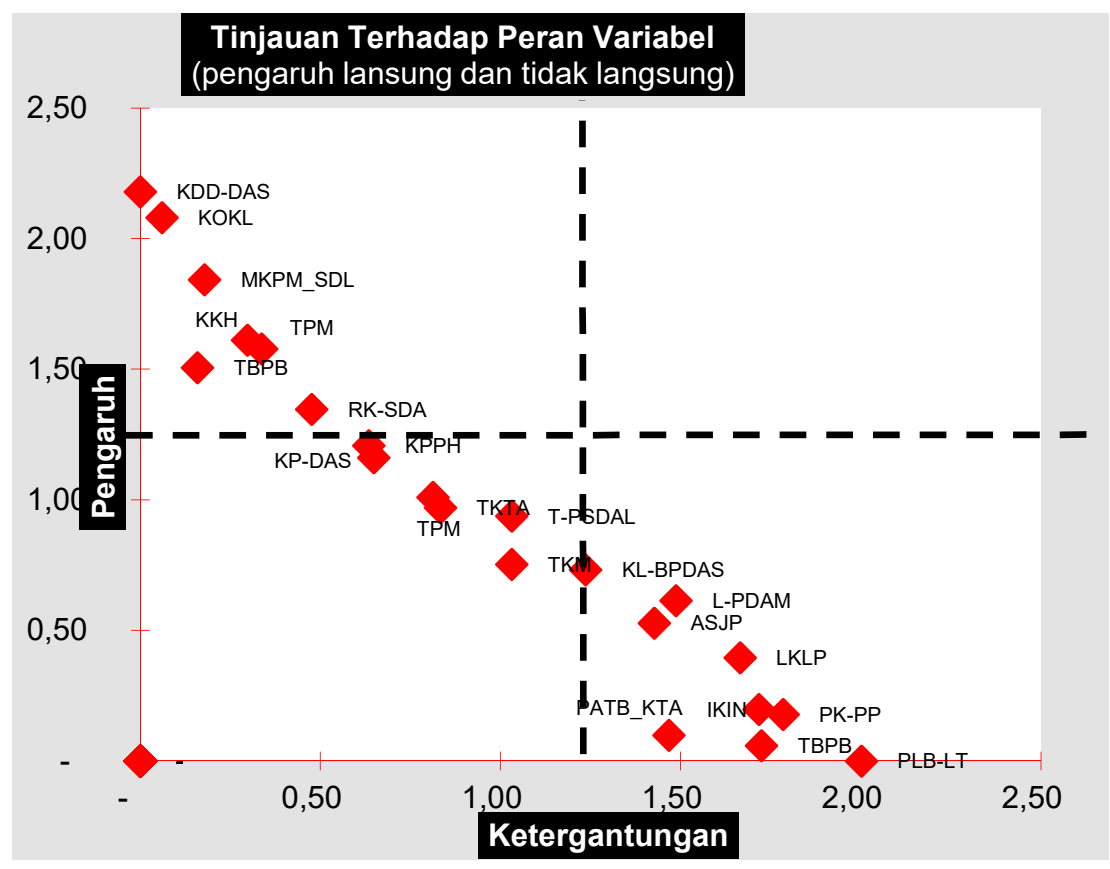

Gambar 3 Hasil analisis tingkat pengaruh Faktor pada pengelolaan bagian tengah DAS Aesesa Flores.

Berdasarkan hasil yang disajikan pada Gambar 3, nampak bahwa tipe pola sebaran faktor-faktor pengungkit dalam kuadran adalah membentuk diagonal antara kuadran I dan III. Tipe sebaran variabel tersebut menunjukkan indikasi sistem yang dibangun stabil (Bourgeois 2007). Hasil analisis prospektif terhadap pengelolaan bagian tengah DAS-AF diperoleh 7 (tujuh) faktor/variabel yang berada pada kuadran I (kuadran input) yang merupakan kuadran variabel penentu (driving variabels), terdiri atas; a) KDD-DAS (kapasitas daya dukung DAS), b) KOKL (kapasitas organisasi dan koordinasi lembaga/instansi stakeholders terkait, c) MKPM-SDAL (motivasi dan kepedulian serta partisipasi masyarakat terhadap pengelolaan dan pengendalian SDAL), d) Tingkat pendapatan masyarakat, e) TBPB (teknologi budidaya dan pengolahan bambu), f) KKH (kekeringan dan kebakaran hutan), dan g) RK-SDA (rezim kepemilikan SDA pada DAS). Ketujuh faktor/variabel tersebut merupakan variabel penentu dalam pengelolaan bagian tengah DAS-AF secara berkelanjutan.

\section{Faktor Dominan Pengelolaan Bagian Hilir DAS Aesesa Flores}

Bagian hilir DAS adalah suatu wilayah daratan bagian dari DAS yang dicirikan dengan topografi datar sampai landai, merupakan daerah endapan sedimen atau aluvial.Ciri atau karakteristik DAS bagian hilir, meliputi; 1) Merupakan kawasan yang sangat datar/landai dan mendekati muara sungai, 2) Aliran sungai sangat 
lambat, 3) Banyak dijumpai aliran sungai yang berkelok-kelok (meander), 4) Banyak terdapat kali mati (oxbow lake) yaitu aliran meander yang terpotong, 5) Merupakan daerah dataran banjir (flood plain) yang cukup luas, 6) Bentuk lembah sangat lebar, dan 7) Banyak dijumpai bantaran sungai sebagai hasil sedimentasi lumpur dan pasir-pasir halus. Bagian hilir didasarkan pada fungsi pemanfaatan air sungai yang dikelola untuk dapat memberikan manfaat bagi kepentingan sosial dan ekonomi, yang diindikasikan melalui kuantitas dan kualitas air, kemampuan menyalurkan air, ketinggian curah hujan, dan terkait untuk kebutuhan pertanian, air bersih, serta pengelolaan air limbah (Asdak 2010). Di bagian hilir terdapat Mbay sebagai ibukota Kabupaten Nagekeo juga pesisir pantai dan juga terdapat hamparan sawah yang cukupu luas yang kesemuanya akan komplikatif pengelolaannya.

Berdasarkan hasil analisis pada Gambar 4 diperoleh bahwa tipe pola sebaran faktor-faktor pengungkit dalam kuadran adalah membentuk diagonal antara kuadran I dan III. Tipe sebaran variabel tersebut menunjukkan indikasi sistem yang dibangun valid. Hasil analisis prospektif terhadap pengelolaan bagian hilir DAS-AF diperoleh 7 (tujuh) faktor/variabel yang berada pada kuadran I (kuadran input) yang merupakan kuadran variabel penentu (driving variabels), terdiri atas; a) KDD-DAS (kapasitas daya dukung DAS), b) KOKL (kapasitas organisasi dan koordinasi lembaga/instansi stakeholders terkait, c) MKPM-SDAL (motivasi dan kepedulian serta partisipasi masyarakat terhadap pengelolaan dan pengendalian SDAL), d) Tingkat pendapatan masyarakat, e) TBPB (teknologi budidaya dan pengolahan bambu), f) KKH (kekeringan dan kebakaran hutan), dan g) PK-PP (Penataan Kawasan Permukiman Pesisir). Ketujuh faktor/variabel tersebut merupakan variabel penentu dalam pengelolaan DAS-AF bagian hilir secara berkelanjutan.

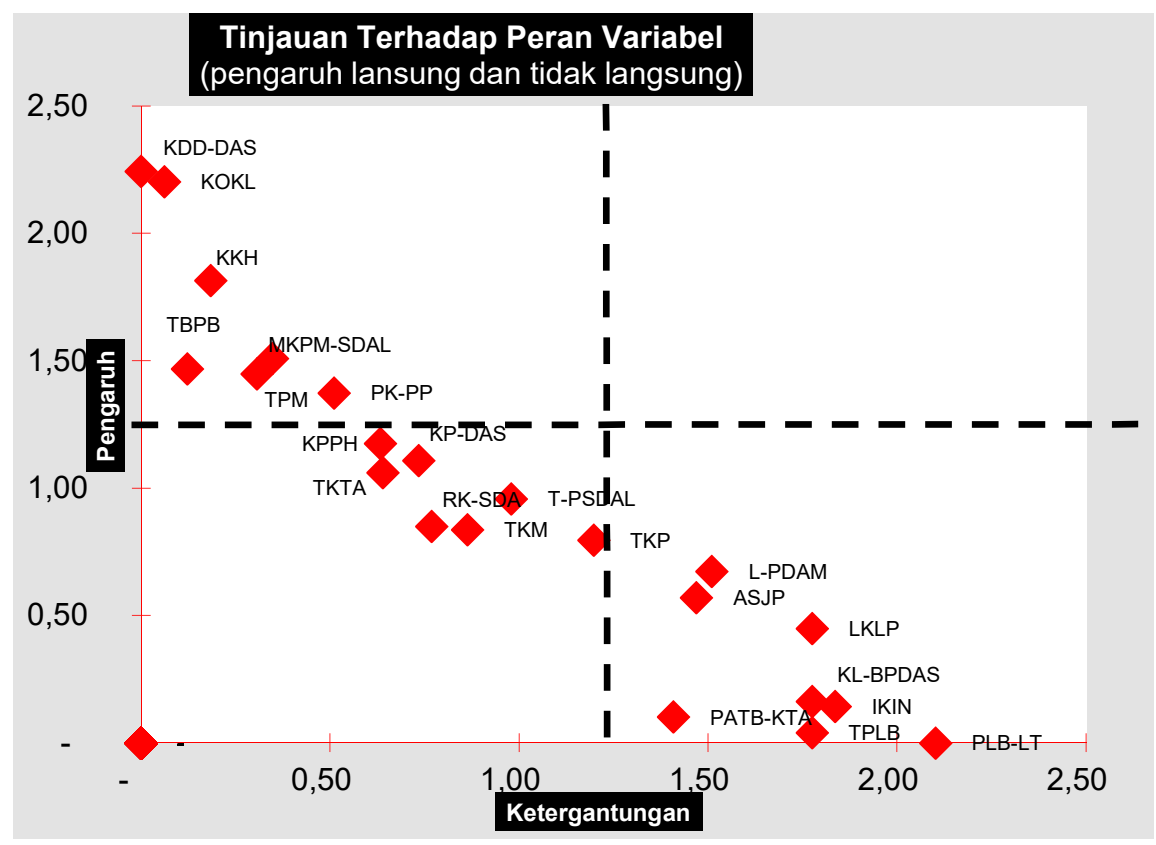

Gambar 4 Hasil analisis tingkat pengaruh Faktor pada pengelolaan bagian hilir DAS Aesesa Flores.

\section{Altenatif Pengembangan Kebijakan Pengelolaan Berkelanjutan DAS Aesesa Flores}

Faktor dominan hasil analisis prospektif untuk ketiga bagian DAS AF sebagaimana disajikan pada Gambar 1, 2 dan 3 menunjukan bahwa terdapat 7 (tujuh) faktor kunci pada setiap bagian. Lima faktor diantaranya adalah sama pada setiap bagiannya, yakni: 1) kapasitas daya dukung DAS; 2) kapasitas organisasi dan koordinasi lembaga/instansi stakeholders terkait; 3) motivasi dan kepedulian serta partisipasi masyarakat terhadap pengelolaan dan pengendalian SDAL; 4) tingkat pendapatan masyarakat; dan 5) teknologi budidaya dan pengelolaan bambu. Sedangkan dua faktor kunci yang berbeda, yang mencirikan interaksi antara karakteristik biogeokimia dan permasalahan sosial-ekonomi lingkungan pada masing-masing bagian DAS AF, 
yaitu: 1) perluasan areal tanaman bambu dan tanaman KTA lainnya dan kapasitas lembaga/instansi stakeholders BPDAS di bagian hulu; 2) kekeringan dan kebakaran hutan dan rezim kepemilikan SDA pada DAS di bagian tengah; dan 3) kekeringan dan kebakaran hutan serta penataan kawasan permukiman dan pesisir di bagian hilir.

Kapasitas daya dukung DAS merupakan salah satu faktor penentu pengelolaan DAS-AF secara berkelanjutan. Daya dukung lingkungan DAS dapat diartikan sebagai kemampuan DAS dalam menyediakan sumberdaya alam dan lingkungan ataupun menunjang pemanfaatannya. Disisi lain, DAS diharapkan mampu menjaga sumberdaya cadangan termasuk menjaga kualitas sumberdaya. Untuk suatu sistem yang terbuka, maknanya adalah bahwa sistem tersebut mampu menyediakan sumberdaya (bahan mentah, barang dan jasa) dan mampu pula menghasilkan produk dan menampung limbah hasil proses produksi. Menurut Asdak dan Salim (2006) menyebutkan bahwa untuk mewujudkan pengelolaan sumberdaya berkelanjutan, maka perencanaan pengelolaan sumberdaya harus berlandaskan pada daya dukung (carrying capacity) ekosistem. Lebih jauh disebutkan bahwa konsep proses perencanaan tata ruang berbasis daya dukung lingkungan adalah jalan menuju terwujudnya pengelolaan sumberdaya berkelanjutan.

Daya dukung suatu wilayah tidak bersifat statis ( a fixed amount), tetapi bervariasi sesuai dengan kondisi biogeokimia (ekologis) wilayah termaksud dan juga kebutuhan (demand) manusia akan SDA dan jasa lingkungan (goods and services) dari wilayah tersebut. Daya dukung suatu wilayah dapat menurun akibat kegiatan manusia maupun faktor-faktor alamiah (natural forces), contohnya bencana alam. Adanya inovasi teknologi tidak meningkatkan daya dukung wilayah akan tetapi berperan dalam meningkatkan efisiensi penggunaan sumber daya alam. Hasil analisis data menunjukan kondisi DAS AF saat ini; di bagian hulu dalam kondisi rusak, dan dalam kondisi sedang untuk bagian tengah dan hilir, dan secara umum kondisi daya dukung DAS AF saat ini memerlukan pemulihan tinggi. Dengan terjaganya daya dukung tersebut, maka pengelolaan DAS AF dapat terjaga dan berkelanjutan.

Kapasitas organisasi dan koordinasi lembaga/instansi stakeholders terkait dan kapasitas lembaga/instansi stakeholders BPDAS adalah dua variabel yang juga menjadi penentu keberlanjutan pengelolaan DAS AF. Menurut Kapucu et al. (2011) kapasitas merupakan suatu sumberdaya, tingkat kepemimpinan, kemampuan atau keahlian masyarakat yang memadai, tingkatan tertentu pada pelembagaan (perubahan hal-hal baru yang bernilai baik). Kapasitas institusi atau kelembagaan dapat dilihat dari level-level kapasitas masyarakatnya yaitu tingkat sistem, tingkat organisasi, dan tingkat individu. Kapasitas kelembagaan tingkat sistem terdiri dari hubungan antar individu, kelompok informal, dan organisasi formal yang menghasilkan jaringan hubungan sosial yang disebut dengan modal sosial. Terdapat ada tiga faktor yang dapat diidentifikasi dari pengaturan kelembagaan yakni: konherensi kepentingan dan aktivitas diantara para pihak, kekuatan lembaga lokal, dan manfaat untuk masyarakat lokal.

Pengaturan kelembagaan akan semakin mudah dilakukan jika ada kesamaan kepentingan diantara para pihak dan adanya kejelasan identitas serta besaran (ukuran) kelompok masing-masing para pihak. Kapasitas organisasi pada akhirnya akan mempengaruhi kinerja organisasi tersebut. Kapasitas kelembagaan mencakup sumberdaya, pengetahuan, dan proses yang digunakan organisasi tersebut untuk mencapai tujuannya. Ini terdiri atas fisik, infrastruktur, teknologi, sumberdaya keuangan, kepemimpinan strategis, program dan manajemen serta jaringan dan hubungan dengan organisasi lain. Dengan demikian, menjadi sangat penting untuk menjaga dan meningkat kapasitas organisasi serta koordinasi antara lembaga atau stakeholders terkait pengelolaan DAS AF.

Motivasi dan kepedulian serta partisipasi masyarakat terhadap pengelolaan dan pengendalian SDAL juga merupakan faktor penentu dalam pengelolaan DAS AF. Motivasi, kepedulian dan partisipasi masyarakat akan sangat berpengaruh terhadap cara dan tingkat pemanfaatan dan pengelolaan sumberdaya alam dan lingkungan yang ada di wilayah DAS AF. Partisipasi masyarakat dalam pembangunan diartikan sebagai ikut sertanya masyarakat dalam pembangunan, ikut dalam kegiatan pembangunan dan ikut serta memanfaatkan dan ikut menikmati hasil-hasil pembangunan (Suryono 2001). 
Motivasi diartikan sebagai dorongan yang timbul pada diri seseorang secara sadar atau tidak sadar untuk melakukan suatu tindakan dengan tujuan tertentu, atau usaha-usaha yang dapat menyebabkan seseorang atau kelompok orang tertentu tergerak melakukan sesuatu karena ingin mencapai tujuan yang dikehendakinya atau mendapat kepuasan dengan perbuatannya. Sedangkan yang objektif adalah satu barang atau keadaan yang berada di luar seseorang yang biasa disebut dengan istilah insentif atau rangsangan atau goal atau sasaran atau tujuan. Motivasi selanjutnya yang akan mempengaruhi tindakan individu (seseorang), termasuk juga dalam pemanfaatan dan pengelolaan sumberdaya alam dan lingkungan. Sedang partispasi masyarakat diartikan adalah keikutsertaan masyarakat dalam proses pengidentifikasian masalah dan potensi yang ada di masyarakat, pemilihan dan pengambilan keputusan tentang alternatif solusi untuk menangani masalah, pelaksanaan upaya mengatasi masalah, dan ketertiban masyarakat dalam proses mengevaluasi perubahan yang terjadi (Isbandi, 2007). Dengan demikian, motivasi, perilaku dan partispasi masyarakat dalam pengelolaan SDAL menjadi sangat penting, khususnya dalam menjaga keberlangsungan DAS AF.

Tingkat pendapatan masyarakat menjadi salah satu faktor penentu pengelolaan DAS AF secara berkelanjutan. Tingkat pendapatan masyarakat akan sangat mempengaruhi preferensi masyarakat dalam pemanfaatan sumberdaya alam dan lingkungan termasuk sumberdaya DAS. DAS AF memiliki sumber daya alam (SDA) yang cukup besar dan beragam seperti pertanian dan pariwisata, namun sampai saat ini potensi setiap sektor tersebut belum secara optimal dapat memberikan nilai tambah yang signifikan untuk mensejahterakan rakyat dan daerah Ngada dan Nagekeo. Hal ini disebabkan karena masih kurangnya investasi yang dilakukan dan masih tingginya kemiskinan. Sejalan dengan adanya kebijakan otonomi daerah, pemerintah daerah kini berwenang penuh merancang dan melaksanakan kebijakan dan program pembangunan sesuai dengan kebutuhannya, sehingga diperlukan seperangkat kebijakan yang dapat meningkatkan pendapatan masyarakat.

Tingkat pendapatan masih menjadi indikator utama tingkat kesejahteraan masyarakat, disamping berbagai indikator sosial ekonomi lainnya. Pendapatan maayarakat adalah jumlah penghasilan yang diterima oleh para anggaota masarakat dalam waktu tertentu sebagai balas jasa atas faktor-faktor produksi yang mereka sumbangkan. Dengan demikian, sumber pendapatan utama masyarakat di wilayah pedesaan termasuk juga sebagian besar masyarakat di wilayah DAS AF adalah pemanfaatan sumberdaya alam dan jasa-jasa lingkungan seperti; kegiatan pertanian, perkebunan dan lain sebagainya. Untuk itu, tekanan terhadap keberlangsungan sumberdaya alam dan lingkungan di wilayah DAS AF akan sangat dipengaruhi pula oleh tingkat pendapatan masyarakat yang ada disekitar wilayah DAS AF.

Teknologi budidaya dan pengelolaan bambu adalah faktor/variabel yang juga merupakan variabel penentu dalam pengelolaan DAS AF. Suatu wilayah DAS dapat berkelanjutan dengan pengelolaan yang baik ataupun dengan penerapan teknologi. Teknologi budidaya dan pengelolaan bambu merupakan salah satu teknologi yang sangat dibutuhkan oleh masyarakat dalam menjaga keberlanjutan pengelolaan DAS AF. Hal tersebut dikarenakan pengelolaan bambu oleh masyarakat di DAS AF sudah membudaya walaupun masih secara tradisional budidaya dan pemanfaatannya. Sumber utama bambu saat ini adalah selain dibudidayakan oleh masyarakat dan juga dari alam, sehingga dapat dipastikan dengan tingkat pemanfaatan yang terus menerus dan masif, dikarenakan nilai ekonominya yang relatif baik setelah dilakukan pengolahan serta secara sosial budaya telah dimanfaatkan secara turun temurun, seperti dalam pesta adat maupun kegiatan masyarakat lainnya menyebabkan tekanan pemanfaatan bambu menjadi tinggi.

Teknik budidaya bambu diperlukan untuk menambah populasi bambu yang cenderung berkurang yang disebabkan oleh beralihnya fungsi lahan yang digunakan untuk pemukiman atau diganti dengan komoditi tanaman lain yang dianggap lebih menguntungkan. Sementara itu kebutuhan bahan baku bambu terus meningkat sejalan dengan pertumbuhan penduduk dan perkembangan kemajuan ilmu pengetahuan. Budidaya bambu bermanfaat selain untuk menjaga ketersediaan suplai juga untuk meningkatkan kualitas bambu untuk memenuhi permintaan pasar. 
Untuk itu, kebutuhan akan teknologi budidaya dan pengelolaan bambu menjadi sangat vital, demi menjaga keberlangsungannya. Disisi lain, bambu yang tumbuh disepanjang daerah sepadan sungai DAS AF tersebut memiliki fungsi ekologis yang sangat baik. Hal tersebut tampak dari kegiatan Utthan Centre dalam upaya konservasi pada lahan bekas penambangan batu di India melakukan penanaman hutan bambu seluas 106 ha, dimana dalam waktu 4 tahun kemudian permukaan air bawah tanah meningkat 6.3 meter dan seluruh areal penanaman menghijau serta memberi pekerjaan kepada sekitar $80 \%$ penduduk setempat dan menambah pendapatan masyarakat melalui industri kerajinan bambu (Garland 2004). Hasil studi Akademi Beijing dan Xu Xiaoging, melakukan inventarisasi dan perencanaan hutan dengan melakukan studi banding hutan pinus dan bambu pada DAS ternyata bambu menambah $240 \%$ air bawah tanah lebih besar dibandingkan hutan pinus (Garland 2004).

Kekeringan dan kebakaran hutan merupakan salah satu penyebab terjadinya degradasi lahan dan berkurangnya sumber air yang lebih disebabkan oleh faktor alam yakni udara panas dan kemarau panjang. Kekeringan dan kebakaran hutan $(\mathrm{KKH})$ merupakan salah satu faktor/atribut penentu dalam pengelolaan berkelanjutan DAS-AF bagian tengah. Atribut ini menjadi khas dan pembeda dengan bagian hulu dan hilir, mengingat bagian tengah memiliki potensi semak belukar dan kawasan hutan yang lebih dominan dibandingkan dengan lahan terbukanya. Minimnya aktivitas penduduk di bagian tengah DAS AF, seperti masih kurangnya penduduk dan permukiman, serta kegiatan pertanian yang relatif kurang bila dibandingkan dengan bagian hulu dan hilir. Disisi lain potensi kebakaran hutan, bersumber dari aktivitas pembukaan lahan oleh masyarakat untuk kegiatan bercocok tanam dan berburu adat.

Tingkat penutupan lahan bervegetasi merupakan indikator baik tidaknya ekosistem termasuk DAS di suatu wilayah. Lahan diartikan sebagai lingkungan fisik yang terdiri atas iklim, relief, tanah, air dan vegetasi serta benda yang diatasnya sepanjang ada pengaruhnya terhadap penggunaan lahan, termasuk didalamnya hasil kegiatan manusia dimasa lalu dan sekarang seperti hasil reklamasi laut, pembersihan vegetasi dan juga hasil yang merugikan seperti yang tersaliniasi (Arsyad 2010). Vegetasi mempunyai peranan penting dan sangat berpengaruh terhadap erosi di suatu tempat. Dengan adanya vegetasi tanah dapat terlindung dari bahaya kerusakan tanah oleh butiran hujan.

Tutupan lahan bervegetasi merupakan bagian penting bagi kehidupan masyarakat di wilayah perkotaan, peningkatan jumlah penduduk terutama di kota Bajawa Kabupaten Ngada di hulu dan kota Mbay Kabupaten Nagekeo berdampak pada pengalihfungsian lahan bervegetasi menjadi area terbangun sehingga mengurangi luas tutupan lahan bervegetasi kota. Tutupan lahan adalah kondisi kenampakan biofisik permukaan bumi yang diamati. Penggunaan lahan adalah pengaturan, kegiatan dan input terhadap jenis tutupan lahan tertentu untuk menghasilkan sesuatu, mengubah atau mempertahankannya. Analisis akan lebih efektif jika data yang dihasilkan dari kedua istilah tersebut digabungkan karena memungkin mendeteksi lokasi perubahan terjadi, perubahan tipe dan bagaimana suatu lahan berubah.

Penataan Kawasan Permukiman dan Pesisir merupakan salah satu upaya rekayasa sosial yang diselenggarakan di suatu wilayah dan dilakukan bersamaan dengan upaya menciptakan suatu sistem yang komprehensif terkait aktivitas yang berlangsung di kawasan, dengan memperhatikan kualitas lingkungan hidup. Hal ini berarti yang diharapkan dari Penataan Kawasan adalah hadirnya suatu tatanan baru yang dapat memberikan harapan kualitas kehidupan yang lebih meningkat. Diharapkan proses dan hasil penataan kawasan merupakan bagian dari upaya mendidik perilaku warga masyarakat sekitar dan juga merupakan pendidikan bagi para pengguna manfaat dari kawasan tersebut agar sesuai dengan tujuan Penataan Kawasan. Penataan kawasan dengan konsep seperti ini bermaksud untuk: (1) mengembangkan kehidupan sosial masyarakat setempat; (2) meningkatkan ekonomi masyarakat setempat; serta (3) mengembangkan kualitas lingkungan dan menjaga kelestarian lingkungan. Hal ini sejalan dengan proses pembangunan berkelanjutan, yang mempertimbangkan aspek sosial, ekonomi, dan lingkungan (Rustiadi et al. 2009). 
Penaataan kawasan permukiman dan pesisir juga merupakan penataan ruang atau tata ruang wilayah. Penataan ruang adalah suatu sistem proses perencanaan tata ruang, pemanfaatan tata ruang dan pengendalian pemanfaatan ruang (Undang-Undang Nomor 26 Tahun 2007 tentang Penataan Ruang). Saat ini DAS AF belum memiliki RTRW sendiri dan masih masuk dalam penataan RTRW Kabupaten Ngada dan Nagekeo. Demikian halnya dengan kawasan pesisir belum ditata secara baik. Perencanaan tata ruang adalah suatu proses untuk menentukan struktur ruang dan pola ruang yang meliputi penyusunan dan penetapan rencana tata ruang. Pada Undang-Undang Penataan Ruang, perencanaan rencana tata ruang wilayah nasional, rencana tata ruaang wilayah provinsi, dan rencana tata ruang wilayah kabupaten/kota mencakup ruang darat, ruang laut, dan ruang udara, termasuk ruang di dalam bumi. Penataan kawasan yang baik akan meningkatkan daya dukung suatu kawasan.

Rezim kepemilikan SDA atau lazim dikenal property rights menjadi salah satu instrumen kebijakan dalam pembangunan berkelanjutan. Instrumen property rights dalam pengelolaan sumberdaya alam dan lingkungan, termasuk dalam pengelolaan DAS AF secara berkelanjutan sangat penting, mengingat sifat sumberdaya yang umumnya bebas akses, sehingga tekanan terhadap sumberdaya dan lingkungan sulit terkendali. Rezim kepemilikan merupakan bentuk penguasaan sumberdaya alam. Penguasaan sumberdaya alam tersebut sangat menentukan bentuk pengelolaan yang akan dilakukan. Kondisi saat ini rezim kepemilikan SDA pada DAS AF didominasi oleh milik perorangan dan juga komunal dan asih banyak tanah ulayat yang dikuasai oleh satu orang atau suku saja. Pengaturan hak kepemilikan diharapkan dapat menjadi insentif dalam pengalokasian sumberdaya yang efisien. Hal ini menjadi sangat penting, sebab sumberdaya yang bersifat umum (open access) akan sangat sulit dikendalikan (tidak terkontrol), sehingga kegagalan pasar dapat terjadi kapan saja. Sumberdaya yang bersifat open access dapat memunculkan terjadinya "the tragedy of commonds" (Kartodihardjo et al 2004).

Perluasan areal tanaman bambu dan tanaman KTA lainnya menjadi sangat penting mengingat banyaknya manfaat yang dapat diperoleh dari tanaman bambu tersebut, baik manfaat ekologi, ekonomi, hingga sosial budaya. Masyarakat Bali Desa Pakraman Angseri telah sukses menggunakan bambu sebagai tanaman hutan rakyat seluas 12 ha, ternyata telah membantu menjaga dan memulihkan aliran air bawah tanah dan mata air panas, meningkatkan pendapatan masyarakat sekitar hutan bambu untuk usaha kerajinan serta menunjang kehidupan komunitas kera untuk dijadikan sebagai tempat wisata (Sumantera dan Peneng 2005). China selain pertimbangan nilai konservasi menana hutan bambu untuk kepentingan sumber air dan irigasi terdapat perhitungan ekonomis yang memiliki nilai komersial tinggi, didukung nilai adat dan budaya telah melakukan penanaman hutan bambu seluas 4.3 juta ha yang mampu menghasilkan bambu sebanyak 14.2 juta ton/tahun. Kondisi hutan bambu di China telah mencapai $3 \%$ dari total hutan dan telah berhasil memberi kontribusi sekitar 25\% dari total ekspor sebesar US \$2.8 milyar (Garland 2004).

Prioritas penanaman bambu sebagai dasar pengelolaan DAS AF secara berkelanjutan juga selaras dengan keputusan Kementerian Lingkungan Hidup dan Kehutanan (KLHK), yang telah menetapkan Kabupaten Ngada sebagai pusat unggulan untuk program 1000 desa bambu sebagai suatu platform dalam mengembangkan dan memperkuat pemanfaatan bambu di Indonesia melalui industri bambu berbasis masyarakat. Program 1000 desa bambu di Kabupaten Ngada mulai dijalankan tahun 2018 ini (Ekawati 2018). Hal menarik lainnya adalah Kabupaten Kepulauan Mentawai, Sumatera Barat telah membangun dan oleh PLN telah menoperasikan satu dari tiga pembangkit listrik tenaga biomasa (PLTBM) bambu (Nugraha et al. 2018).

Pertimbangan menggunakan bambu sebagai tanaman untuk penghijauan karena memiliki pertumbuhan sangat cepat, investasi kecil, tidak membutuhkan perawatan khusus, dalam usia 3 - 5 tahun telah memperoleh pertumbuhan mantap dan dapat dipanen setiap tahun. Selain itu dapat dilakukan penanaman campuran secara silang dengan tanaman berkayu (pohon) untuk tujuan pemulihan fungsi hutan kembali dalam jangka pendek. Walaupun komoditi bambu ini sudah membudaya dikalangan masyarakat disekitar DAS AF, namun secara luas masih sangat kecil yakni di bagian hulu $\pm 15 \%$, bagian tengah $\pm 8 \%$, dan bagian hilir paling kecil $\pm 5 \%$ luasannya. Sehingga tidak akan berpengaruh besar secara ekologi, ekonomi dan sosial jika tidak diperluas areal tanaman bambu juga tanaman konservasi tanah dan air lainnya. 


\section{SIMPULAN}

Terdapat 10 (sepuluh) faktor kunci yang menjadi dasar untuk meningkatkan kinerja pengelolaan DAS AF menjadi berkelanjutan. Kesepuluh agenda tersebut meliputi faktor: 1) kapasitas daya dukung DAS, (2) kapasitas organisasi dan koordinasi lembaga/instansi stakeholders terkait, 3) motivasi dan kepedulian serta partisipasi masyarakat terhadap pengelolaan dan pengendalian SDAL, 4) Tingkat pendapatan masyarakat, 5) teknologi budidaya dan pengelolaan bambu. 6) rezim kepemilikan SDA, 7) kekeringan dan kebakaran hutan, 8) penataan kawasan permukiman dan pesisir, 9) tingkat penutupan lahan bervegetasi, dan 10) perluasan areal tanaman bambu dan tanaman KTA lainnya. Dua diantara sepuluh faktor kunci adalah faktor yang dipengaruhi oleh tanaman bambu.

Pengembangan tanaman bambu menjadi komoditi keberlanjutan pengelolaan DAS AF sangat prospektif karena didukung oleh budaya masyarakat, iklim, kertersediaan lahan dan pasar. Rekomondasi alternatif kebijakan dan program pengelolaan DAS AF adalah "Pengembangan bambu untuk mendorong ketersediaan listrik energi biomasa bambu dan perekonomian masyarakat desa. Untuk dapat merealisasikannya diperlukan kesiapan dan kemampuan pemerintah daerah sebagai pembuat dan pelaksana kebijakan untuk meningkatkan status keberlanjutan DAS AF yang didukung oleh stakeholders terutama masyarakat.

\section{UCAPAN TERIMA KASIH}

Penelitian ini dapat dilaksanakan berkat dukungan dan sponsor dari Pemerintah Kabupaten Ngada - NTT, dan para pejabat pemerintahan dari tingkat desa/kelurahan dan kecamatan di Kabupaten Ngada dan Nagekeo, serta para pakar. Kami juga ingin mengucapkan terima kasih kepada semua pihak termasuk keluarga yang telah berkontribusi baik langsung maupun tak langsung yang sangat bervariasi dan berharga dalam menyukseskan penelitian ini.

\section{DAFTAR PUSTAKA}

[PRI] Pemerintah Republik Indonesia. 2007. Penataan Ruang. Undang-Undang Republik Indonesia Nomor 26 Tahun 2007. Jakarta: Sekretariat Negara.

[PRI] Pemerintah Republik Indonesia. 2012. Pengelolaan Daerah Aliran Sungai. Peraturan Pemerintah Republik Indonesia Nomor 37 Tahun 2012. Jakarta: Sekretariat Negara.

Asdak C. 2010. Hidrologi dan Pengelolaan Daerah Aliran Sungai, Yogyakarta: Gajah Mada University Press.

Asdak C. Salim H. 2006: Daya Dukung Sumberdaya Air Sebagai Pertimbangan Penataan Ruang. Jurnal Teknik Lingkungan. P3TL-BPPT. 7 (1): 16 - 25.

Bourgeois R, Jesus F. 2004. Participatory Prospective Analysis, Exploring and Anticipating Challenges with Stakeholders. Center for Alleviation of Poverty through Secondery Crops Development in Asia and The Pacific and French Agricultural Research Center for International Development. CGPRT Publication (ESCAP) No. 46. Bogor.

Bourgeois R. 2007. Analisis Prospektif Partisipatif. Bahan Pelatihan/Lokakarya. Training of Trainer. Bogor (ID): ICASEPS.

Dunn WN. 2000. Pengantar Analisis Kebijakan Publik. Indonesian Edition. Edisi Kedua. Yogyakarta: Gadjah Mada University Press.

Ekawati D. 2018. Ngada jadi pusat unggulan program 100 desa bamboo. Sumber: https://kupang.antaranews.com/berita/7662/ngada-jadi-pusat-unggulan-program-1000-desa-bambu.

Garland L. 2004. Bamboo and Watersheds (a practical, economic solution to conservation and development). EBF Environmental Bamboo Foundation Holland. Bamboo: The Alternative for Tropical Timber. The Environmental Bamboo Foundation Journal No. 1.

Godet M. 2010. Future memories. Technological Forecasting \& Social Change. 77: 1457-1463.

Hardjomidjojo H. 2007. Sistem Dinamik: Konsep Sistem dan Permodelan untuk Industri dan Lingkungan. Bogor: SEAMEO Biotrop. 
Hora SC. 2004. Probability judgments for continuous quantities: linear combinations and calibration. Management Science. 50 (1): 597-604.

Isbandi R.A. 2007. Perencanaan Partisipatoris Berbasis Aset Komunitas: Dari Pemikiran Menuju Penerapan. Depok: Fisip UI Press.

Kapucu N, Healy BF, Arslan T. 2011. Survival of the fittest: Capacity building for small nonprofit organizations. Evaluation and Program Planning. 34(3): 236-245. doi:http://dx.doi.org/10.1016/ j.evalprogplan.2 011.03.005

Kartodihardjo H, Murtilaksono K, Sudadi U. 2004. Institusi Pengelolaan Daerah Aliran Sungai: Konsep dan Pengantar Analisis Kebijakan. Bogor: Fakultas Kehutanan IPB.

Koli Y. 2010. Mengubah Cagar Alam Watu Ata, Sebuah Pengalaman Advokasi Kebijakan Publik. Bajawa: Sloka Institute, Lapmas Ngada, dan Veco Indonesia.

Noywuli N, Rachman LM, Sapei A, Satriawan H. 2017a. Prasyarat Penyusunan Kebijakan Pengelolaan Terpadu dan Berkelanjutan DAS Aesesa Flores Propinsi NTT. Prosiding Seminar Nasional Pengelolaan Daerah Aliran Sungai (DAS) Secara Terpadu. LPPM UNRI (2018): 341-348.

Noywuli N, Sapei A, Pandjaitan NH, Eriyatno. 2017b. Dinamika Sosial Ekonomi dan Kelembagaan Dalam Pengelolaan Terpadu dan Berkelanjutan DAS Aesesa Flores Propinsi NTT. Prosiding Seminar Nasional Pengelolaan Daerah Aliran Sungai (DAS) Secara Terpadu. LPPM UNRI (2018): 349-360.

Noywuli N., Sapei A, Pandjaitan NH, Eriyatno. 2019. Assessment of Watershed Carrying Capacity for the Aesesa Flores Watershed Management, East Nusa Tenggara Province of Indonesia. Environment and Natural Resources Journal. 17(2). Retrieved from https://www.tcithaijo.org/index.php/ennrj/article/view/186810

Nugraha I, Saturi S, Suprapto Y. 2018. Cerita Seputar Listrik Energi Bambu di Mentawai. www.mongabay.co.id.

Pujiono E, Setyowati R. 2015. Penilaian Tingkat Kerentanan Sumber Daya Air Terhadap Variabilitas Iklim di DAS Aesesa, Pulau Flores, Nusa Tenggara Timur (Vulnerability Assessment of Water Resources to Climate Variability in Aesesa Waterhed, Flores Island, East Nusa Tenggara). Jurnal Penelitian Sosial dan Ekonomi Kehutanan. 12(3):177-195.

Ramadhan B. 2016. Kabupaten Ngada Dikenal Sebagai Kabupaten Sejuta Bambu. Sumber: https://www.goodnewsfromindonesia.id/2016/02/22/kabupaten-ini-dikenal-sebagai-kabupaten-sejutabambu.

Rustiadi E, Saefulhakim S, Panudju DR. 2009. Perencanaan dan Pengembangan Wilayah. Bogor: IPB Press.

Sumantera IW, Peneng IN. 2005. Pemberdayaan Hutan bambu sebagai penunjang sosial ekonomi masyarakat Desa Pakraman Angseri, tabanan, Bali. Prosiding Perkembangan Bambu Indonesia. Jogyakarta.

Surya RA. 2015. Kebijakan pengelolaan SDA untuk penyediaan air baku berkelanjutan di tingkat kabupaten (studi kasus Kabupaten Konawe Propinsi Sulawesi Tenggara) [disertasi]. Bogor. Sekolah Pascasarjana Institute Pertanian Bogor.

Suryono A. 2001. Teori dan Isi Pembangunan. Malang: Universitas Negeri Malang. UM Press.

Suwarno J. 2011. Pengembangan kebijakan pengegelolaan berkelanjutan DAS Ciliwung Hulu Kabupaten Bogor [disertasi]. Bogor. Sekolah Pascasarjana Institut Pertanian Bogor.

Widnyana IK. 2011. Bambu Dengan Berbagai Manfaatnya. Bakti Saraswati. 1(2). ISSN : 2088-2149. 